\title{
$17: 29714365-29711512$
}

National Cancer Institute

\section{Source}

National Cancer Institute. 17:29714365-29711512. NCI Thesaurus. Code C41856.

Physical location of CCL1_Gene 